\title{
Artificial Inoculation of AM Fungi Improves Nutrient Uptake Efficiency in Salt Stressed Pea (Pissum Sativum L) Plants
}

\author{
Eriola Meça \\ Technology Transfer Center of Fushe Kruja, Fushe Kruje, Albania \\ Glenda Sallaku \\ Department of Horticulture and Landscape Architecture, Agricultural University of Tirana, \\ Tirana, Albania \\ Astrit Balliu (corresponding author) \\ Department of Horticulture and Landscape Architecture, Agricultural University of Tirana, \\ Tirana, Albania
}

Received: May 12, 2016

Accepted: June 9, 2016

Published: June 11, 2016

doi:10.5296/jas.v4i3.9585

URL: http://dx.doi.org/10.5296/jas.v4i3.9585

\begin{abstract}
The study aimed to investigate the effects of commercially available AMF inoculate (Glomussp. mixture) on the growth and the nutrient acquisition of field pea (Pissum sativumL) plants. Inoculated (AMF+) and non-inoculated (AMF-) pea plants were subjected to two levels of salinity by the addition of sodium chlorate into the tap water $(0$ and $50 \mathrm{mM} \mathrm{NaCl})$. Several times during the growing cycle, in randomly selected plants the morphology of root system was analyzed and the dry matter of roots and the aboveground biomass were individually measured. Furthermore, plant tissue samples were analyzed regarding N, P and $K$ concentration and the total uptake and specific absorption rate of these elements $\left(\mathrm{SAR}_{\mathrm{N}}\right.$, $\mathrm{SAR}_{\mathrm{P}}, \mathrm{SAR}_{\mathrm{K}}$ ) per unit of root length, root surface area and root volume were calculated. Saline irrigation water strongly diminished the growth of pea plants and strongly reduced the absorption capacity of their root system. The inoculation of AM fungi in the growing substrate contributed to the increase of plant biomass and alleviation of the salinity stress by improving the specific absorption rate of main nutrient elements by the root system. Therefore, the artificial inoculation of AM fungi could be considered as an effective alternative to improve growth of pea plants under saline irrigation water conditions.
\end{abstract}

Keywords: root length, root surface area, root morphology, specific absorption rate, nitrogen, 
phosphorous, potassium

\section{Introduction}

Though pea (Pisum sativum L.) is grown essentially for its protein-rich seeds (Tayeh, Klein, et al., 2015), it is also an essential component of sustainable cropping systems, due to its ability to develop symbiotic nitrogen fixation as well as its role as a break crop for pest and pathogen reduction (Tayeh et al., 2015). Growing pea would improve soil quality by enhance the N-supplying power of soils, increase the soil reserves of organic matter, stimulate soil biological activity, improve soil structure, increase soil aeration, improve soil water-holding capacity and make the soil easier to till.

Unfortunately, like most of legumes, pea is very sensitive to salinity (Egamberdieva et al. 2013). Plants growing in saline soils are subjected to the toxic effects of specific ions such as sodium and chloride, which disrupt the structure of enzymes and other macromolecules, damage cell organelles and disrupt photosynthesis and respiration. Soil salinity also induces a physiological drought in the plant and produces nutrient imbalance due to decreased nutrient uptake and/or transport to the shoot (Porcel et al., 2016).

Apart from intrinsic protective systems, plants can overcome salinity effects by interacting with several beneficial soil microorganisms such as arbuscular mycorrhizal fungi (AMF). This widespread coexistence of plants and fungi has important consequences for plant mineral nutrition, water acquisition, carbon allocation, tolerance to abiotic and biotic stresses and interplant competition (Jansa et al., 2013). The improved salt tolerance of AM plants has been attributed to a more efficient uptake of nutrients, protection of enzyme activities, increase in photosynthesis ability, facilitation of water uptake by plants and mitigation of ionic imbalance (Porcel et al., 2016).

Unfortunately, modern cultivation techniques have resulted in progressively reduced AM fungal diversity and frequency in agricultural soils and potting substrates, an effect that is believed to be related to tillage methods, the use of mineral fertilizers and nursery substrate sterilization among other factors (Nouriet al., 2014). Under these circumstances, the use of commercial inoculants containing arbuscular mycorrhizal fungi (AMF) is quickly expanding, rewarded as an environmentally friendly technology which contributes to the alleviation of the negative effects of soil/irrigation water salinity.

In line with the above considerations, the objective of this study was to assess the impact of AMF inoculants containing a mixture of AM fungi ( $G$. intraradices, $G$. etunicatum, $G$. mosseae, G. geosporum, and G. clarum) on plant growth parameters and nutrient absorption capacity of field pea (Pissum sativum L) under normal and saline conditions.

\section{Materials and methods}

\subsection{Plant material and experimental conditions}

The experiment was conducted in a non heated greenhouse at Agricultural University of Tirana, Tirana, Albania. For that purpose, graded seeds of a commercial pea cultivar (Progress 9) were sown in large plastic pots $(0.6 \mathrm{~m} \times 0.2 \mathrm{~m} \times 0.2 \mathrm{~m})$ filled either with i) 
vermiculite (Agra-Vermiculite, Pull Rhenen B.V., The Netherlands) + peat moss (Potground H) (vol:vol; 2:1) and 10\% (vol/vol) crushed, expanded clay particles coated with AM-fungal spores ( 200 spores $\mathrm{g}^{-1}$; mixture of Glomus intraradices, Glomus etunicatum, Glomus mosseae, Glomus geosporum, and Glomus clarum supplied by BioSym B.V. (Hengelo, Netherlands); AMF+, or ii) vermiculite + peat moss (2:1) with crushed, spore-free expanded clay particles $(10 \% \mathrm{vol} / \mathrm{vol})$; AMF-. The clay particles with / without AMF spores were homogenously mixed with the substrate before sowing. To each pot, 40 graded seeds, sown $2 \mathrm{~cm}$ apart from each other at $2 \mathrm{~cm}$ depth, in two parallel lines. The seeds were sown in December 10, 2014 and the experiment lasted till May 30, 2015.

Two different levels of salt-stress $(0$ and $50 \mathrm{mM} \cdot \mathrm{NaCl})$ were established by the addition of different amounts of sodium chloride $(\mathrm{NaCl})$ to the irrigation water. The non-inoculated $(\mathrm{AMF}-)$ and inoculated (AMF+) plants were equally distributed to both salinity treatments, according to a full factorial design. Consequently, four treatments, i.e., control (AMF-, no $\cdot \mathrm{NaCl}$ ), salt stress without mycorrhizal inoculation (AMF-, $50 \mathrm{mM} \cdot \mathrm{NaCl})$, mycorrhizal only $(\mathrm{AMF}+\mathrm{no} \cdot \mathrm{NaCl})$, and salt stress with mycorrhizal inoculation $(\mathrm{AMF}+, 50 \mathrm{mM} \cdot \mathrm{NaCl})$ were established. Each treatment was represented by 7 pots placed in row alongside each other; each of them represented a replication.

Plants were watered during the whole experimental period with equal amounts of either tap water $(0 \mathrm{mMNaCl})$, or saline water $(50 \mathrm{mMNaCl})$. The irrigation was conducted by a gravity driven drip irrigation system ( 2 drippers per pot, with $0.2 \mathrm{~L} \mathrm{hrs}^{-1}$ discharge rate). For that purpose, individual $200 \mathrm{~L}$ deposits were placed over a $2 \mathrm{~m}$ high platform. The time, frequency and length of irrigation cycles were automatically controlled by an electronic irrigation controller (Itec 8, NetafimLtd, Israel).

\subsection{Plant sampling and measurements}

At DAS (day after sowing) 18 and 42, ten plants of each treatment were randomly selected and harvested. The root system was gently washed free of adhering vermiculate particles, and scanned with an Epson Expression/STD 4800 Scanner. Subsequently, the acquired root images were analyzed with WinRHIZO Arabidopsis software (Regent Instruments Inc., Quebec, Canada), and the growth parameters of root system; root length (RL), root surface area (RSA), and root volume (RV) were measured and recorded. The plant organs were subsequently dried $\left(65^{\circ} \mathrm{C}, 48 \mathrm{~h}\right)$ and dry matter of roots $\left(\mathrm{DM}_{\text {Root }}\right)$ and the aboveground biomass $\left(\mathrm{DM}_{\text {Shoot}}\right)$ were weighted separately to an accuracy of $0.001 \mathrm{~g}$ (TP 303; Denver Instruments $\mathrm{GmbH}$, Göttingen, Germany).

\subsection{Chemical analyses and nutrient uptake efficiency calculations}

The whole plant material (roots + shoots) was mixed together, grounded and analyzed for nutrient content(N, P, K), respectively at DAS18 and 42. Following that, the total uptake of each nutrient accumulated in the plant was calculated as the product of leaf dry matter and nutrient concentration(Amor \& Marcelis, 2005)(Y. Huang et al., 2013),

$\mathrm{X}$ accumulation $(\mathrm{mg})=\mathrm{X}$ concentration $\left(\mathrm{mg} \mathrm{g}^{-1}\right) \times$ plant dry weight $(\mathrm{g})$. 
and specific absorption rates (SAR) regarding root length, root surface area and root volume ( $\mathrm{g}$ $\left.\mathrm{cm}^{-1} \mathrm{~d}^{-1}, \mathrm{~g} \mathrm{~cm}^{-2} \mathrm{~d}^{-1}, \mathrm{~g} \mathrm{~cm}^{-2} \mathrm{~d}^{-1}\right)$ as indicators of root absorption efficiency were calculated according to the following formulae adopted from Amor \& Marcelis (2005);

$$
\left(\mathrm{X}_{\mathrm{t} 2}-\mathrm{X}_{\mathrm{t} 1}\right) /(\mathrm{t} 2-\mathrm{t} 1) \times\left(\ln _{\mathrm{t} 2}-\ln _{\mathrm{t} 2}\right) /\left(\mathrm{w}_{\mathrm{t} 2}-\mathrm{w}_{\mathrm{t} 1}\right),
$$

where; X1 and X2 is plant nutrient content $(\mathrm{mg})$ at the start and at the end of analyzed period,

$\mathrm{w}_{\mathrm{t} 2}$ and $\mathrm{w}_{\mathrm{t} 1}$ are accordingly root length (RL), root surface area (RA) and root volume $(\mathrm{RV})$ at the start and at the end of analyzed period,

$\mathrm{t} 1=$ start of analyzed period (DAS 18), and $\mathrm{t} 2=$ end of analyzed period (DAS 42).

\subsection{Statistics}

A ten replicate complete randomized factorial block design was used. Differences in DM, RL, RSA, RV and SAR were tested between by two way ANOVA, using the PC program StatPlus 2009 (AnalystSoft Inc., Walnut, CA, USA). Each significant ANOVA result $(\mathrm{p}<0.05)$ was followed by Tukey-Kramer test at $\mathrm{p}<0.05$ as post-hoc test to compare pair wise means within and among treatments. Values given throughout the text are means \pm SD.

\section{Results and Discussion}

Salinity is a common and most severe environmental stressor in agriculture (Flowers 2004, Shelden \& Roessner 2013) which is dramatically exacerbated due to pour water quality (Carillo et al., 2011). Serious deleterious effects of salinity on plant growth and productivity are reported by a large number of publications (Edelstein et al., 2011, Porcel et al., 2012, Colla et al., 2012, Balliu et al., 2015). The results of this experiment did also prove that the presence of $\mathrm{NaCl}$ in the irrigation water drastically reduces the growth of pea plants. Though no significant differences were found between control and saline plants regarding the dry matter of root system( $\left(\mathrm{DM}_{\text {Root }}\right)$, soon after the exposure of pea plants to saline water (18 DAS), the differences became statistically significant 42 day after sowing (Table 1). Similarly, significantly and gradually enlarged difference was found between control and saline plants regarding the dry matter of aboveground biomass (DM Shoot+Leaves $_{\text {s }}$ (Tables 1$)$. Forty two day after sowing, the average dry matter of aboveground biomass in saline plants was only about 0.265 gr plant $^{-1}$ versus 0.297 gr plant $^{-1}$ in AMF- and 0.434 gr plant $^{-1}$ in AMF+ non salined plants.

That increasing deleterious effects of salinity over the plant growth could be explained by the two-phase growth response to salinity (Munns, 2002). According to him, the first phase of growth reduction is essentially a water stress or osmotic phase, and the growth reduction is presumably regulated by hormonal signals coming from the roots. Then there is a second phase of growth reduction, which is due to salts accumulation in transpiring leaves to excessive levels, exceeding the ability of the cells to compartmentalize salts in the vacuole. The consequences of $\mathrm{Na}^{+}$or $\mathrm{Cl}^{-}$build-up in the cell walls are often catastrophic and include dehydration and oxidative stress (Munns 2002, Fatemi 2014), finally causing leaf dieback. 
Table 1. Dry matter (gr) of system $\left(\mathrm{DM}_{\text {Root }}\right)$ and aboveground part $\left(\mathrm{DM}_{\text {Shoots+Leaves }}\right)$ of pea plants with/without arbuscular mycorrhizal fungi (AMF+/AMF-) and under two levels of salinity ( 0 and $50 \mathrm{mM} \mathrm{NaCl}$ ). Different letters indicate significant differences within following parameters (Tukey-Kramer test, $\mathrm{p}<0.05$; mean $\pm \mathrm{SD}$ ).

\begin{tabular}{|c|c|c|c|c|c|}
\hline \multicolumn{2}{|c|}{ Factors } & \multicolumn{4}{|c|}{ Day after sowing (DAS) } \\
\hline \multirow{2}{*}{ AMF } & \multirow{2}{*}{$\begin{array}{l}\text { Salinity } \\
\text { (S) }\end{array}$} & \multicolumn{2}{|c|}{18} & \multicolumn{2}{|c|}{42} \\
\hline & & $\mathrm{DM}_{\text {Roots }}$ & $\mathrm{DM}_{\text {Shoots+Leaves }}$ & DM $_{\text {Roots }}$ & DM $_{\text {Shoots+Leaves }}$ \\
\hline \multirow{2}{*}{ AMF- } & $0 \quad \mathrm{mM}$ & $0.016 \pm 0.003 b$ & $0.058 \pm 0.005 \mathrm{a}$ & $0.084 \pm 0.008 \mathrm{a}$ & $0.297 \pm 0.004 b$ \\
\hline & $50 \mathrm{mM}$ & $0.020 \pm 0.004 \mathrm{ab}$ & $0.047 \pm 0.004 b$ & $0.043 \pm 0.008 b$ & $0.265 \pm 0.003 b$ \\
\hline \multirow{2}{*}{$\mathrm{AMF}+$} & $0 \quad \mathrm{mM}$ & $0.023 \pm 0.004 \mathrm{a}$ & $0.054 \pm 0.008 \mathrm{ab}$ & $0.065 \pm 0.018 \mathrm{a}$ & $0.434 \pm 0.004 a$ \\
\hline & $50 \mathrm{mM}$ & $0.019 \pm 0.005 \mathrm{ab}$ & $0.046 \pm 0.007 \mathrm{~b}$ & $0.037 \pm 0.007 \mathrm{~b}$ & $0.269 \pm 0.002 b$ \\
\hline \multicolumn{6}{|c|}{ Significance } \\
\hline \multicolumn{2}{|c|}{ AMF } & $*$ & $\mathrm{~ns}$ & $*$ & $* * *$ \\
\hline \multicolumn{2}{|c|}{$\mathrm{S}$} & ns & $* * *$ & $* * *$ & $* * *$ \\
\hline \multicolumn{2}{|c|}{$\mathrm{AMF} \times \mathrm{S}$} & $* *$ & ns & ns & $* * *$ \\
\hline
\end{tabular}

Plant biomass production is an integrative measurement of plant performance under many types of abiotic stress conditions, and often the symbiotic efficiency of AM fungi has been measured in terms of plant growth improvement (Porcel et al., 2016). Arbuscular mycorrhizal fungi (AMF) have been frequently reported to improve crop plants' tolerance to stressful abiotic environments such as saline soils, though AMF themselves can be negatively affected by soil salinity (Jahromi et al., 2008). Many reports confirms the improve of growth and performance of mycorrhizal plants under salt stress (J.-C. Huang et al., 2013, Babaj et al., 2014, Vuksani et al., 2015). Though till 42 DAS we did not found any positive effects of AM fungi regarding the dry matter of root system, either under normal or saline condition, the presence of AM fungi has significantly increased the dry matter of aboveground plant part

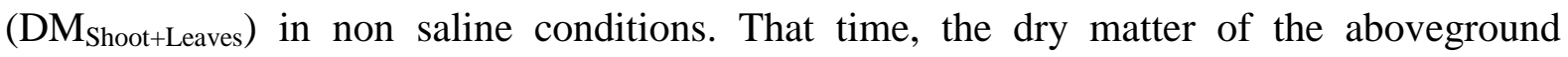
biomass of non salined AMF+ plants reached 0.434 gr plant $^{-1}$ versus 0.297 gr plant $^{-1}$ in AMFplants (Table 2). Anyway, the advantage of mychorrhized (AMF+) over AMF- plants was significant only in non saline conditions; no effect was found under severe salinity conditions (Table 2).

Salinity has strongly affected root morphology of pea plants. The raise of salinity in the irrigation water from $0 \mathrm{mM}$ (control) to $50 \mathrm{mM}$ sodium chlorate $(\mathrm{NaCl})$ was followed by drastic reduction of root length (RL), root surface area (RA) and root volume (RV). The differences between control and saline plants were statistically significant since DAS18, and became more distinguished at DAS 42 (Table 2). These results fits well with previous findings of Aloni et al. (2011), Estañ et al. (2005) and Huang et al. (2009) whose also reported severe inhibition of root development due to increased salinity.

Since specific characteristics of root system, such as root length and surface area, which play an active role in ions and water uptake, would enhance salt tolerance of cultivated plants (Colla et al., 2010, Himmelbauer et al., 2004) it would be of great interest to have any increasing effect of AM fungi on these root parameters. Indeed, we did not found any effect of AM fungi to the root morphology of pea plants. Though, as a common trend, the root 
length, root surface area and root volume of AMF+ plants were slightly smaller compared with AMF- plants under normal conditions and slightly higher under saline conditions, yet, the differences were not statistically significant (Table 2). However, because interconnection of soil with the roots through mycorrhizal fungi is the basis for some of the most important functional features of the mycorrhizal symbiosis, namely the improved uptake of mineral nutrients and/or water from the soil by the host plants (Jansa et al., 2013), significant effects of AMF presence were proved regarding the specific absorption rate of main nutrient elements.

Table 2. Root length (RL; $\mathrm{cm})$, root surface area $\left(\mathrm{RSA} ; \mathrm{cm}^{2}\right)$ and root volume $\left(\mathrm{RV} ; \mathrm{cm}^{3}\right)$ of pea plants with/without arbuscular mycorrhizal fungi (amf+/amf-) and under two levels of salinity ( 0 and $50 \mathrm{mM} \mathrm{NaCl}$ ). Different letters indicate significant differences within following parameters (Tukey-Kramer test, $\mathrm{p}<0.05$; mean $\pm \mathrm{SD}$ ).

\begin{tabular}{|c|c|c|c|c|c|c|c|}
\hline \multicolumn{2}{|c|}{ Factors } & \multicolumn{6}{|c|}{ Day after sowing (DAS) } \\
\hline \multirow{2}{*}{ AMF } & \multirow{2}{*}{$\begin{array}{l}\text { Salinity } \\
(\mathrm{S})\end{array}$} & \multicolumn{3}{|c|}{18} & \multicolumn{3}{|c|}{42} \\
\hline & & $\mathrm{RL}$ & RSA & RV & RL & RSA & RV \\
\hline \multirow{2}{*}{ AMF- } & $0 \quad \mathrm{mM}$ & $82.3 \pm 13.8 \mathrm{a}$ & $23.0 \pm 2.9 \mathrm{a}$ & $0.47 \pm 0.08 \mathrm{a}$ & $171.1 \pm 17 \mathrm{a}$ & $35.9 \pm 5.4 \mathrm{a}$ & $0.57 \pm 0.10 \mathrm{a}$ \\
\hline & $50 \mathrm{mM}$ & $57.5 \pm 14.8 b$ & $14.9 \pm 1.8 \mathrm{~b}$ & $0.31 \pm 0.04 b$ & $120.2 \pm 22 b$ & $24.4 \pm 5.4 \mathrm{~b}$ & $0.40 \pm 0.08 b$ \\
\hline \multirow{2}{*}{$\mathrm{AMF}+$} & $0 \quad \mathrm{mM}$ & $81.5 \pm 14.0 \mathrm{a}$ & $20.6 \pm 5.1 \mathrm{a}$ & $0.43 \pm 0.08 \mathrm{a}$ & $155.7 \pm 23 a$ & $31.6 \pm 5.3 \mathrm{a}$ & $0.50 \pm 0.08 \mathrm{a}$ \\
\hline & $50 \mathrm{mM}$ & $67.6 \pm 13.1 \mathrm{~b}$ & $19.9 \pm 2.5 b$ & $0.39 \pm 0.05 b$ & $121.1 \pm 13 b$ & $26.5 \pm 1.9 \mathrm{~b}$ & $0.42 \pm 0.06 \mathrm{~b}$ \\
\hline \multicolumn{8}{|c|}{ Significance } \\
\hline \multicolumn{2}{|c|}{$\mathrm{AMF}$} & ns & ns & ns & ns & $\mathrm{ns}$ & ns \\
\hline \multicolumn{2}{|c|}{$\mathrm{S}$} & $* *$ & $* *$ & $* *$ & $* *$ & $* * *$ & $* * *$ \\
\hline \multicolumn{2}{|c|}{ AMF $x \mathrm{~S}$} & ns & ns & ns & ns & $\mathrm{ns}$ & $\mathrm{ns}$ \\
\hline
\end{tabular}

The symbiosis of plants with AM fungi often results in increased nutrient uptake (Abdel Latef \& Chaoxing 2011, Evelin et al., 2012, Balliu et al., 2015). Many authors links the role of AM fungi in salinity stress alleviation with the increased uptake rate of P and K (Al-Karaki 2006, Evelin et al., 2009, Abdel Latef \& Chaoxing, 2011) by developing an extensive hyphal network and the higher hyphae affinity to a lower threshold concentration for absorption than in plant roots (Evelin et al., 2009, Evelin et al., 2012). We analyzed the specific absorption rate (SAR) as an indicator of root absorption efficiency; the daily amount of nutrient absorbed, respectively per unit of root length $\left(\mathrm{mg} \mathrm{cm}^{-1} \mathrm{~d}^{-1}\right)$, root surface area $\left(\mathrm{mg} \mathrm{cm}^{-2} \mathrm{~d}^{-1}\right)$ and root volume $\left(\mathrm{mg} \mathrm{cm}^{-3} \mathrm{~d}^{-1}\right)$ and also found significantly higher $\mathrm{N}, \mathrm{P}$ and $\mathrm{K}$ absorption rates due to AM fungi presence (Tables 3, 4, 5). The specific absorption rates of $\mathrm{N}, \mathrm{P}$ and $\mathrm{K}$ in $\mathrm{AMF}+$ plants were more than twice higher than the respective values in AMF- plants, either in non saline or severe salinity conditions. Interestingly, under salinity conditions AMF+ plants were able to reach and even to overpass the respective specific absorption rate per unit of length, area, or volume of the root system of AMF- plants under normal (non saline) conditions (Tables 3, 4, 5) 
Table 3. Nitrogen $(\mathrm{N})$, phosphorus $(\mathrm{P})$ and potassium $(\mathrm{K})$ specific absorption rate in regard to root length $\left(\mathrm{g} \mathrm{cm}^{-1} \mathrm{~d}^{-1}\right)$ (DAS 18 to DAS 42) of pea plants with/without arbuscular mycorrhizal fungi (AMF+/AMF-) and under two levels of salinity ( 0 and $50 \mathrm{mM} \mathrm{NaCl}$ ). Different letters indicate significant differences within following parameters (Tukey-Kramer test, $\mathrm{p}<0.05$; mean $\pm \mathrm{SD}$ ).

\begin{tabular}{|c|c|c|c|c|}
\hline \multicolumn{2}{|c|}{ Factors } & \multicolumn{3}{|c|}{$\mathrm{g} \mathrm{cm}^{-1} \mathrm{~d}^{-1}$} \\
\hline $\mathrm{AMF}$ & Salinity (S) & $\mathrm{N}$ & $\mathrm{P}$ & $\mathrm{K}$ \\
\hline \multirow{2}{*}{ AMF- } & $0 \quad \mathrm{mM}$ & $0.163 \pm 0.06 b$ & $0.049 \pm 0.01 \mathrm{c}$ & $0.087 \pm 0.02 b$ \\
\hline & $50 \mathrm{mM}$ & $0.135 \pm 0.05 b$ & $0.040 \pm 0.01 \mathrm{c}$ & $0.071 \pm 0.03 b$ \\
\hline \multirow{2}{*}{$\mathrm{AMF}+$} & $0 \quad \mathrm{mM}$ & $0.439 \pm 0.10 \mathrm{a}$ & $0.130 \pm 0.03 a$ & $0.264 \pm 0.06 a$ \\
\hline & $50 \mathrm{mM}$ & $0.342 \pm 0.06 \mathrm{a}$ & $0.073 \pm 0.01 \mathrm{~b}$ & $0.101 \pm 0.01 b$ \\
\hline \multicolumn{5}{|l|}{ Significance } \\
\hline $\mathrm{AMF}$ & & $* * *$ & $* * *$ & $* * *$ \\
\hline $\mathrm{S}$ & & $*$ & $* * *$ & $* * *$ \\
\hline $\mathrm{AMF} \times \mathrm{S}$ & & $\mathrm{ns}$ & $* * *$ & $* * *$ \\
\hline
\end{tabular}

Table 4.Nitrogen $(\mathrm{N})$, phosphorus $(\mathrm{P})$ and potassium $(\mathrm{K})$ specific absorption rate in regard to root surface area $\left(\mathrm{g} \mathrm{cm}^{-2} \mathrm{~d}^{-1}\right)$ (DAS 18 to DAS 42) of pea plants with/without arbuscular mycorrhizal fungi (AMF+/AMF-) and under two levels of salinity ( 0 and $50 \mathrm{mM} \mathrm{NaCl}$ ). Different letters indicate significant differences within following parameters (Tukey-Kramer test, $\mathrm{p}<0.05$; mean $\pm \mathrm{SD}$ ).

\begin{tabular}{llccc}
\hline \multicolumn{2}{c}{ Factors } & \multicolumn{5}{c}{$\mathrm{g} \mathrm{cm}^{-2} \mathrm{~d}^{-1}$} \\
\hline AMF & Salinity $(\mathrm{S})$ & $\mathrm{N}$ & $\mathrm{P}$ & $\mathrm{K}$ \\
\hline \multirow{2}{*}{ AMF- } & $0 \mathrm{mM}$ & $0.116 \pm 0.04 \mathrm{~b}$ & $0.034 \pm 0.01 \mathrm{c}$ & $0.061 \pm 0.01 \mathrm{~b}$ \\
& $50 \mathrm{mM}$ & $0.093 \pm 0.03 \mathrm{~b}$ & $0.026 \pm 0.01 \mathrm{c}$ & $0.047 \pm 0.02 \mathrm{~b}$ \\
AMF+ & $0 \mathrm{mM}$ & $0.292 \pm 0.07 \mathrm{a}$ & $0.086 \pm 0.02 \mathrm{a}$ & $0.176 \pm 0.04 \mathrm{a}$ \\
& $50 \mathrm{mM}$ & $0.213 \pm 0.02 \mathrm{a}$ & $0.048 \pm 0.00 \mathrm{~b}$ & $0.067 \pm 0.01 \mathrm{~b}$ \\
\hline Significance & & & & $* * *$ \\
AMF & & $*$ & $* * *$ & $* * *$ \\
S & & $\mathrm{ns}$ & $*$ & $* * *$ \\
AMF x S & & & & $*$ \\
\hline
\end{tabular}

Table 5. Nitrogen $(\mathrm{N})$, phosphorus $(\mathrm{P})$ and potassium $(\mathrm{K})$ specific absorption rate in regard to root volume $\left(\mathrm{g} \mathrm{cm}^{-3} \mathrm{~d}^{-1}\right)$ (DAS 18 to DAS 42) of pea plants with/without arbuscular mycorrhizal fungi (AMF+/AMF-) and under two levels of salinity (0 and $50 \mathrm{mM}$ $\mathrm{NaCl}$ ). Different letters indicate significant differences within following parameters (Tukey-Kramer test, $\mathrm{p}<0.05$; mean \pm SD)

\begin{tabular}{lcccc}
\hline \multicolumn{2}{l}{ Factors } & \multicolumn{3}{c}{$\mathrm{g} \mathrm{cm}^{-3} \mathrm{~d}^{-1}$} \\
\hline AMF & Salinity (S) & $\mathrm{N}$ & $\mathrm{P}$ & $\mathrm{K}$ \\
\cline { 3 - 5 }
\end{tabular}




\begin{tabular}{|c|c|c|c|c|}
\hline \multirow{2}{*}{ AMF- } & $0 \quad \mathrm{mM}$ & $0.099 \pm 0.01 \mathrm{c}$ & $0.030 \pm 0.00 \mathrm{~b}$ & $0.054 \pm 0.01 b$ \\
\hline & $50 \mathrm{mM}$ & $0.117 \pm 0.03 c$ & $0.035 \pm 0.01 b$ & $0.063 \pm 0.01 b$ \\
\hline \multirow{2}{*}{$\mathrm{AMF}+$} & $0 \quad \mathrm{mM}$ & $0.244 \pm 0.04 b$ & $0.074 \pm 0.01 \mathrm{a}$ & $0.152 \pm 0.03 \mathrm{a}$ \\
\hline & $50 \mathrm{mM}$ & $0.381 \pm 0.07 \mathrm{a}$ & $0.081 \pm 0.01 \mathrm{a}$ & $0.113 \pm 0.02 \mathrm{a}$ \\
\hline \multicolumn{5}{|l|}{ Significance } \\
\hline $\mathrm{AMF}$ & & $* * *$ & $* * *$ & $* * *$ \\
\hline $\mathrm{S}$ & & $* *$ & ns & ns \\
\hline $\mathrm{AMF} \times \mathrm{S}$ & & $* *$ & $\mathrm{~ns}$ & $*$ \\
\hline
\end{tabular}

\section{Conclusion}

Saline irrigation water strongly diminishes the growth of pea plants and strongly reduces the absorption capacity of its root system. The inoculation of AM fungi in the growing substrate could help to increase plant biomass and alleviate salinity stress effects by improving the absorption capacity of plants' root system. Therefore, the artificial inoculation of AM fungi could be considered as an effective and environmentally friendly alternative to improve the performance of pea plants under saline irrigation water conditions.

\section{Acknowledgement}

This results are part of the work conducted in the framework of EUROLEGUME Project (Enhancing of legumes growing in Europe through sustainable cropping for protein supply for food and feed), founded by 7th Research Framework Programme of the European Union (FP7 Research Project No. 61378).

\section{References}

Abdel Latef, A. A. H., \& Chaoxing, H. (2011). Effect of arbuscular mycorrhizal fungi on growth, mineral nutrition, antioxidant enzymes activity and fruit yield of tomato grown under salinity stress. Scientia Horticulturae. http://doi.org/10.1016/j.scienta.2010.09.020

Al-Karaki, G. N. (2006). Nursery inoculation of tomato with arbuscular mycorrhizal fungi and subsequent performance under irrigation with saline water. Scientia Horticulturae. http://doi.org/10.1016/j.scienta.2006.02.019

Aloni, B., Karni, L., Deventurero, G., Cohen, R., Katzir, N., Edelstein, M., \& Aktas, H. (2011). The Use of Plant Grafting and Plant Growth Regulators for Enhancing Abiotic Stress Tolerance in Vegetable Transplants, 255-264.

Amor, F. M. D. E. L., \& Marcelis, L. F. M. (2005). Growth and physiological response of tomato plants to different periods of nitrogen starvation and recovery, 80, 147-153.

Babaj, I., Sallaku, G., \& Balliu, A. (2014). The effects of endogenous mycorrhiza ( Glomus spp .) on plant growth and yield of grafted cucumber ( Cucumis sativum 1 ) under common commercial greenhouse conditions, 13(2), 24-28.

Balliu, A., Sallaku, G., \& Rewald, B. (2015). AMF Inoculation Enhances Growth and Improves the Nutrient Uptake Rates of Transplanted, Salt-Stressed Tomato Seedlings, 15967-15981. http://doi.org/10.3390/su71215799

Carillo, P., Annunziata, M. G., Pontecorvo, G., Fuggi, A., \& Woodrow, P. (2011). Salinity 
Stress and Salt Tolerance. Salinity Stress and Salt Tolerance, Abiotic Stress in Plants-Mechanisms and Adaptations, 21-38.

Colla, G., Rouphael, Y., Leonardi, C., \& Bie, Z. (2010). Role of grafting in vegetable crops grown under saline conditions. Scientia Horticulturae, 127(2), 147-155. http://doi.org/10.1016/j.scienta.2010.08.004

Colla, G., Rouphael, Y., Rea, E., \& Cardarelli, M. (2012). Grafting cucumber plants enhance tolerance to sodium chloride and sulfate salinization. Scientia Horticulturae, 135, 177-185. http://doi.org/10.1016/j.scienta.2011.11.023

Edelstein, M., Plaut, Z., \& Ben-Hur, M. (2011). Sodium and chloride exclusion and retention by non-grafted and grafted melon and Cucurbita plants. Journal of Experimental Botany, 62(1), 177-184. http://doi.org/10.1093/jxb/erq255

Egamberdieva, D., Jabborova, D., Wirth, S., Egamberdieva, D., Jabborova, @ bullet D, \& Wirth, S. (n.d.). Alleviation of Salt Stress in Legumes by Co-inoculation with Pseudomonas and Rhizobium. http://doi.org/10.1007/978-81-322-1287-4_11

Estañ, M. T., Martinez-Rodriguez, M. M., Perez-Alfocea, F., Flowers, T. J., \& Bolarin, M. C. (2005). Grafting raises the salt tolerance of tomato through limiting the transport of sodium and chloride to the shoot. Journal of Experimental Botany, 56(412), 703-712. http://doi.org/10.1093/jxb/eri027

Evelin, H., Giri, B., \& Kapoor, R. (2012). Contribution of Glomus intraradices inoculation to nutrient acquisition and mitigation of ionic imbalance in $\mathrm{NaCl}$-stressed Trigonella foenum-graecum. Mycorrhiza, 22(3), 203-217. http://doi.org/10.1007/s00572-011-0392-0

Evelin, H., Kapoor, R., \& Giri, B. (2009). Arbuscular mycorrhizal fungi in alleviation of salt stress: A review. Annals of Botany, 104(7), 1263-1280. http://doi.org/10.1093/aob/mcp251

Fatemi, S. N. (2014). Ascorbic Acid and Its Effects on Alleviation of Salt Stress in Sunflower, $4(24), 3656-3665$.

Flowers, T. J. (2004). Improving crop salt tolerance. Journal of Experimental Botany, 55(396), 307-319. http://doi.org/10.1093/jxb/erh003

Himmelbauer, M. L., Loiskandl, W., \& Kastanek, F. (2004). Estimating length, average diameter and surface area of roots using two different Image analyses systems. Plant and Soil, 260(1-2), 111-120. http://doi.org/10.1023/B:PLSO.0000030171.28821.55

Huang, J.-C., Lai, W.-A., Singh, S., Hameed, A., \& Young, C.-C. (2013). Response of mycorrhizal hybrid tomato cultivars under saline stress. Journal of Soil Science and Plant Nutrition, 13(132), 469-484.

Huang, Y., Li, J., Hua, B., Liu, Z., Fan, M., \& Bie, Z. (2013). Grafting onto different rootstocks as a means to improve watermelon tolerance to low potassium stress. Scientia Horticulturae, 149(August 2015), 80-85. http://doi.org/10.1016/j.scienta.2012.02.009

Huang, Y., Zhu, J., Zhen, A., Chen, L., \& Bie, Z. (2009). Organic and inorganic solutes accumulation in the leaves and roots of grafted and ungrafted cucumber plants in response to $\mathrm{NaCl}$ stress. Journal of Food, Agriculture and Environment, 7(2), 703-708.

Jahromi, F., Aroca, R., Porcel, R., \& Ruiz-Lozano, J. M. (2008). Influence of Salinity on the In Vitro Development of Glomus intraradices and on the In Vivo Physiological and Molecular 


\section{Macrothink}

Responses of Mycorrhizal Lettuce Plants. Microbial Ecology, 55(1), 45-53. http://doi.org/10.1007/s00248-007-9249-7

Jansa, J., Bukovská, P., Gryndler, M., Miransari, M., \& Yannarell, A. (2013). Mycorrhizal hyphae as ecological niche for highly specialized hypersymbionts - or just soil free-riders? http://doi.org/10.3389/fpls.2013.00134

Munns, R. (2002). Comparative physiology of salt and water stress. Plant, Cell \& Environment, 25(2), 239-250. http://doi.org/10.1046/j.0016-8025.2001.00808.x

Nouri, E., Breuillin-Sessoms, F., Feller, U., \& Reinhardt, D. (2014). Phosphorus and nitrogen regulate arbuscular mycorrhizal symbiosis in petunia hybrida. PLoS ONE. http://doi.org/10.1371/journal.pone.0090841

Porcel, R., Aroca, R., Azcon, R., \& Ruiz-Lozano, J. M. (2016). Regulation of cation transporter genes by the arbuscular mycorrhizal symbiosis in rice plants subjected to salinity suggests improved salt tolerance due to reduced $\mathrm{Na}+$ root-to-shoot distribution. Mycorrhiza, (April). http://doi.org/10.1007/s00572-016-0704-5

Porcel, R., Aroca, R., \& Ruiz-Lozano, J. M. (2012). Salinity stress alleviation using arbuscular mycorrhizal fungi. A review. Agronomy for Sustainable Development. http://doi.org/10.1007/s13593-011-0029-x

Shelden, M. C., \& Roessner, U. (2013). Advances in functional genomics for investigating salinity stress tolerance mechanisms in cereals. Frontiers in Plant Science, 4(May), 123. http://doi.org/10.3389/fpls.2013.00123

Tayeh, N., Aubert, G., Pilet-Nayel, M.-L., Lejeune-Hénaut, I., Warkentin, T. D., \& Burstin, J. (2015). Genomic Tools in Pea Breeding Programs: Status and Perspectives. Frontiers in Plant Science, 6(November). http://doi.org/10.3389/fpls.2015.01037

Tayeh, N., Klein, A., Le Paslier, M.-C., Jacquin, F., Houtin, H., Rond, C., ... Burstin, J. (2015). Genomic Prediction in Pea: Effect of Marker Density and Training Population Size and Composition on Prediction Accuracy. Frontiers in Plant Science, 6(November), 1-11. http://doi.org/10.3389/fpls.2015.00941

Vuksani, A., Sallaku, G., \& Balliu, A. (2015). ( Open Access ) The Effects of Endogenous Mycorrhiza ( Glomus spp .) on Stand Establishment Rate and Yield of Open Field Tomato Crop, 14(1), 25-30.

\section{Copyright Disclaimer}

Copyright for this article is retained by the author(s), with first publication rights granted to the journal.

This is an open-access article distributed under the terms and conditions of the Creative Commons Attribution license (http://creativecommons.org/licenses/by/3.0/). 